\title{
PAYMENTS FOR ENVIRONMENTAL SERVICES (PES): CHALLENGES AND OPPORTUNITIES FOR RURAL PRODUCERS AT SENHORA DE OLIVEIRA, MINAS GERAIS
}

\author{
Bruno Leão Said Schettini ${ }^{1}$, Marcelo Gomes da Silva Pereira ${ }^{2}$, Laércio Antônio Gonçalves Jacovine ${ }^{3}$, Samuel \\ José Silva Soares da Rocha ${ }^{4}$, Paulo Henrique Villanova ${ }^{5}$, Indira Bifano Comini ${ }^{6}$ \\ ${ }^{1}$ Universidade Federal de Viçosa, Departamento de Engenharia Florestal, Viçosa, Minas Gerais, Brasil. Bruno.schettini@ufv.br* \\ ${ }^{2}$ Universidade Federal de Viçosa, Departamento de Engenharia Florestal, Viçosa, Minas Gerais, Brasil. Marcelosantos.florestal@ gmail.com \\ ${ }^{3}$ Universidade Federal de Viçosa, Departameet. alnto de Engenharia Florestal, Viçosa, Minas Gerais, Brasil. Jacovine@ @ufv.br \\ ${ }^{4}$ Universidade Federal de Viçosa, Departamento de Engenharia Florestal, Viçosa, Minas Gerais, Brasil. Paulo.villanova@ufv.br \\ ${ }^{5}$ Universidade Federal de Viçosa, Departamento de Engenharia Florestal, Viçosa, Minas Gerais, Brasil. Samuel.rocha@ufv.br \\ ${ }^{6}$ Universidade Federal de Viçosa, Departamento de Engenharia Florestal, Viçosa, Minas Gerais, Brasil. Indira.comini@ufv.br
}

Received for publication: 12/06/2019 - Accepted for publication: 06/12/2019

\begin{abstract}
Resumo
Pagamento por Serviços Ambientais (PSA): desafios e oportunidades para produtores rurais em Senhora de Oliveira, Minas Gerais. O Pagamento por Serviços Ambientais (PSA) é uma importante ferramenta para a conservação ambiental e é uma prática relevante em diversos países para manutenção das florestas. Dessa forma o objetivo do presente estudo foi avaliar os desafios e oportunidades de implantação de um programa de Pagamento por Serviços Ambientais no município de Senhora de Oliveira, Minas Gerais. O diagnóstico socioeconômico e ambiental foi realizado pela técnica do Diagnóstico Rápido Participativo. O total de 20 questionários socioeconômicos e ambientais foram aplicados no município, com objetivo de conhecer de forma detalhada a realidade local, levantando potencialidades e demandas. O número de integrantes das 20 famílias que participaram do diagnóstico rural foi de 72, sendo 36 homens e 36 mulheres, com média de 3,6 pessoas por família. Das 20 propriedades rurais que participaram do diagnóstico rural, 35\% possuem áreas de RL delimitadas e nenhuma delas possui plano de manejo. A exploração da Reserva Legal ocorre em 15\% das propriedades avaliadas, sendo a produção de lenha e estacas a atividade predominante. $\mathrm{O}$ valor médio de disposição a receber pelos produtores rurais foi de $\mathrm{R} \$ 220,00 \mathrm{ha}^{-1} \mathrm{ano}^{-1}$, em que não foram considerados aqueles produtores que não responderam a esse questionamento. O município de Senhora de Oliveira, Minas Gerais possui as condições necessárias para implementação do PSA, entretanto os produtores ainda não recebem nenhum incentivo para provisão dos serviços ambientais. Caso se implemente esse processo de Pagamentos por Serviços Ambientais, certamente haverá avanços na conservação ambiental e trará benefícios sociais em toda a região.
\end{abstract}

Palavras-chave: conservação florestal; disposição a receber; protetor recebedor.

Abstract
Payment for Environmental Services (PES) is an important tool for environmental conservation and is a relevant practice in many countries for the maintenance of forests. Thus, the objective of the present study was to evaluate challenges and opportunities of implementing a Payment for Environmental Services program in the municipality of Senhora de Oliveira, Minas Gerais. Socioeconomic and environmental diagnosis was performed using the Rapid Participatory Diagnosis technique. The total of 20 socioeconomic and environmental questionnaires were applied in the municipality, aiming to know in detail the local reality, raising potentialities and demands. The number of members of the 20 families that participated in the rural diagnosis was 72 , of which 36 were men and 36 were women, with an average of 3.6 persons per family. Of the 20 rural properties that participated in the rural diagnosis, $35 \%$ have delimited RL areas and none of them has a management plan. The exploration of Legal Reserve occurs in 15\% of the evaluated properties, being the production of firewood and cuttings the predominant activity. The average value of disposition receivable by rural producers was $\mathrm{R} \$$ $220.00 \mathrm{ha}^{-1} \mathrm{year}^{-1}$, in which the producers who did not respond to this question were not considered. The municipality of Senhora de Oliveira, Minas Gerais has the necessary conditions to implement the PES, however the producers still do not receive any incentive to provide environmental services. If this process of PES is implemented, there will certainly be advances in environmental conservation and will bring social benefits throughout the region.

Keywords: forest conservation; willingness to receive; protector-receiver.

\section{INTRODUCTION}

The concern of the world population about environmental degradation on the planet and its possible impacts is growing and can be exemplified by the different initiatives to reduce deforestation in native forests (GARRETT et al., 2019). The change in land use is responsible for an annual loss of 4,3 to 20,2 trillion dollars in

FLORESTA, Curitiba, PR, v. 51, n. 1, p. 090-098, jan/mar 2021.

Schettini, B. L.S. et.al.

ISSN eletrônico 1982-4688

DOI: $10.5380 /$ rf.v51 i1. 67386 
ecosystem services, and this drives the search for effective alternatives to deal with environmental problems on the planet (COSTANZA et al., 2014).

Payments for Environmental Services (also known as Payments for Ecosystem Services or PES) is an important and promising approach to environmental conservation (SONE et al., 2019) and relevant practice in several countries for reducing environmental problems (WANG; WOLF, 2019). PES consists of the commercialization of some environmental good or service. In this case, a voluntary transaction is necessary, in which a specific seller sells a well-defined ecosystem service for a minimum price, and the supplier ensures the provision of this service (WUNDER, 2005).

The establishment of environmental control policies - including PES programs - follows the Polluter Pays Principle (PPP), which establishes that the polluter must bear the costs of reducing pollution to maintain environmental conditions (VARELA et al., 2017). The Conservative Receiver Principle (CRP), unlike the PPP, defines that rural producers who preserve some environmental good or service receive some remuneration or incentive to protect a specific area (VILAR et al., 2010).

The Brazilian Forestry Code (Law No. 12,651/2012) authorizes PES, with or without monetary remuneration, to the activities of conservation and improvement of ecosystems and which generate environmental services, such as water conservation, climate regulation, maintenance of Permanent Preservation Areas (PPA) and Legal Reserve (RL), and conservation of biodiversity and scenic beauty (BRASIL, 2012). Brazil already has examples of successful recognition in PES programs, such as the cases of the Produtor de Águas (Water Producer) in São Paulo and the Conservador de Águas (Water Conservator) in Minas Gerais, which are the two main projects related to the theme, for the conservation of the Atlantic Forest Biome (RUGGIERO et al., 2019).

PES programs over the past few years have attracted the attention of researchers and implementers of practices for environmental conservation (MURADIAN et al., 2013) due to its various success stories. The knowledge of the local reality by the rural diagnosis must compose the stages for the PES program/project elaboration because it allows identifying the social groups of a specific region, the resources that exist in the place, if there is an environmental good or service to be commercialized, and how socio-environmental interests are articulated (COELHO, 2014). Also, if there are one or more buyers interested in this environmental good or service, for this reason, it is an early step for the success and implementation of a PES program/project.

Thus, the objective of this study was to evaluate the challenges and opportunities of Payments for Environmental Services to rural producers in the municipality of Senhora de Oliveira, Minas Gerais.

\section{MATERIAL AND METHODS}

\section{Study area description}

The Xopoto River basin is inserted in the Rio Doce hydrographic basin and has a territorial extension of about $83,400 \mathrm{~km}^{2}$, of which $86 \%$ belong to the state of Minas Gerais and $14 \%$ to Espirito Santo.

The Xopoto River basin belongs to the Atlantic Forest Biome, covered by semideciduous seasonal forests and high biological diversity, resulting not only from local wealth but also from the presence of 23 pronounced environmental gradients, which originated regionally rich fauna and flora. The region climate is of the Cwa type, characterized by moderate temperatures, with hot and rainy summer. The average annual rainfall in the region is approximately $1340 \mathrm{~mm}$, and the predominant soil classes are Red-Yellow Latosol and Red-Yellow Podzolic.

\section{Participatory Rapid Diagnosis method description}

The socioeconomic and environmental diagnosis was performed using the Participatory Rapid Diagnosis technique (VILAR et al., 2010). This diagnosis was made effective by identifying the main characteristics of the target social group. The activities carried out resulted from the mobilization and contact made by technicians and interns from the Xopoto Institute with technicians from EMATER (Technical Assistance and Rural Extension Company of the State of Minas Gerais) in the municipality of Senhora de Oliveira, Minas Gerais. The researchers went to the rural properties to present and explain to the rural producers the work that was occurring in the municipality of Senhora de Oliveira. Their rural union, together with researchers from the Xopoto Institute and the Federal University of Viçosa, held meetings with union members to clarify the research. At these meetings, producers interested in participating in the study were identified. Twenty socioeconomic and environmental questionnaires were applied in the municipality to know in detail the local reality, raising the potential and demands of the population. The questionnaire was completed through an informal conversation with each rural producer and their families. The following assessments compose the diagnosis: the social, economic, and environmental profile, water resources of the property, and willingness to receive for maintenance of the PPAs. The Xopoto Institute, a partner organization in the research, has a consent form to publish the results of the study. The Institute was responsible for giving feedback to rural producers on the outcomes of the work.

FLORESTA, Curitiba, PR, v. 51, n. 1, p. 090-098, jan/mar 2021. 
The environmental assessment of rural properties was made using the technique of cross-sectional walking, which consists of walking through a specific area, accompanied by local informants who know the region. The route must be represented and annotated, with details of the landscape and asking the informant about issues relevant to that location, such as environmental problems, its situation in the past, present reality, perspectives, potential, and limitations (SOUZA, 2009).

The determination of the soil use and occupation in the properties occurred following the Brazilian Forestry Code (Law No. 12.651/2012) and CONAMA Resolution No. 303/2002 (BRASIL, 2012; CONAMA, 2002). The classification of successional stages of native forest areas followed the criteria defined in CONAMA Resolution No. 392/2007 (CONAMA, 2007). Parameters such as physiognomy, predominant strata, the existence of epiphytes, climbing plants and litter, diversity and dominance of species, and presence of indicator species were evaluated to classify the vegetation in initial, medium, and advanced stages of regeneration.

The environmental characterization of the rural properties occurred during the cross-sectional walk. At this stage occurred the identification of natural resources and their state of conservation. The areas of LR and PPAs, when existing, were identified to diagnose the conservation status of each one, according to the attributes: vegetation, agricultural activities, degraded or eroded areas, water, and soil (Table 1) (PINTO et al., 2004).

Table 1. Attributes used to diagnose the conservation status of Permanent Preservation Areas (PPAs) and Legal Reserves (LR) in the municipality of Senhora de Oliveira-MG-Brazil

Tabela 1. Atributos utilizados para diagnosticar os estados de conservação de Áreas de Preservação Permanente (APPs) e Reservas Legais (RL) no município Senhora de Oliveira, Minas Gerais, Brasil

\begin{tabular}{|c|c|c|c|}
\hline \multirow{2}{*}{ Attribute } & \multicolumn{3}{|c|}{ Conservation state } \\
\hline & Preserved & Disturbed & Degraded \\
\hline Vegetation & $\begin{array}{l}\text { Medium or advanced } \\
\text { stage }\end{array}$ & Early-stage & Absence of vegetation \\
\hline Agricultural activities & Absent & $\begin{array}{l}\text { Crops with low impact } \\
\text { management }\end{array}$ & $\begin{array}{l}\text { Presence of annual crops } \\
\text { (corn and beans) or crops } \\
\text { that generate high } \\
\text { environmental impact, } \\
\text { such as eucalyptus }\end{array}$ \\
\hline Degraded or eroded areas & Absent & Laminar erosion & $\begin{array}{l}\text { Highly degraded or } \\
\text { eroded areas }\end{array}$ \\
\hline Water & $\begin{array}{l}\text { Protected against the } \\
\text { trampling of animals, } \\
\text { against contamination by } \\
\text { animal and human waste, } \\
\text { and pollution by other } \\
\text { residues }\end{array}$ & $\begin{array}{l}\text { Little influence on water } \\
\text { resources }\end{array}$ & $\begin{array}{l}\text { Stepped source; water } \\
\text { with the impossibility of } \\
\text { human or animal } \\
\text { consumption; the history } \\
\text { of decreased water flow } \\
\text { from the springs }\end{array}$ \\
\hline Soil & $\begin{array}{l}\text { Absence of silting in the } \\
\text { case of rivers and } \\
\text { streams, presence of } \\
\text { litter, soil without } \\
\text { compaction }\end{array}$ & $\begin{array}{l}\text { Little soil exposure; } \\
\text { natural regeneration } \\
\text { indicators }\end{array}$ & $\begin{array}{l}\text { Proximity to areas with } \\
\text { potential for soil and } \\
\text { water contamination } \\
\text { (human waste, garbage, } \\
\text { animal waste) }\end{array}$ \\
\hline
\end{tabular}

Techniques of economic valuation of natural resources

The method of evaluating the willingness to pay is to quantify the amount that a consumer would be willing to pay for the use of a natural good or service. The adaptation of this methodology resulted in a willingness to receive, which made it possible to ask the rural producer how much he would be willing to receive to immobilize certain areas of his rural property to guarantee the provision of ecosystem services. Interviews to identify the usevalue that people give to the preservation of specified areas within their rural properties occurred to know how much these people would be willing to receive per hectare per year to keep these areas preserved.

Water resources were evaluated according to its uses on the property, types of resources found (source, stream, brook, river, dam, among others), the form of water abstraction for its use, number of springs, and characterization and evaluation of the conservation state of these areas. Besides, the observation of land use and 
occupation in the areas surrounding rivers, streams, dams, weirs, and barrages was made, as well as the assessment of the conservation status of these regions.

\section{RESULTS}

\section{Social and economic profile}

Seventy-two members from the 20 families participated in the rural diagnosis, 36 men and 36 women, with an average of 3,6 people per family. Their level of education was another assessed social indicator. In Senhora de Oliveira, more than $10 \%$ of the participants have no education level, and the majority (43\%) have incomplete elementary education (Figure 1).
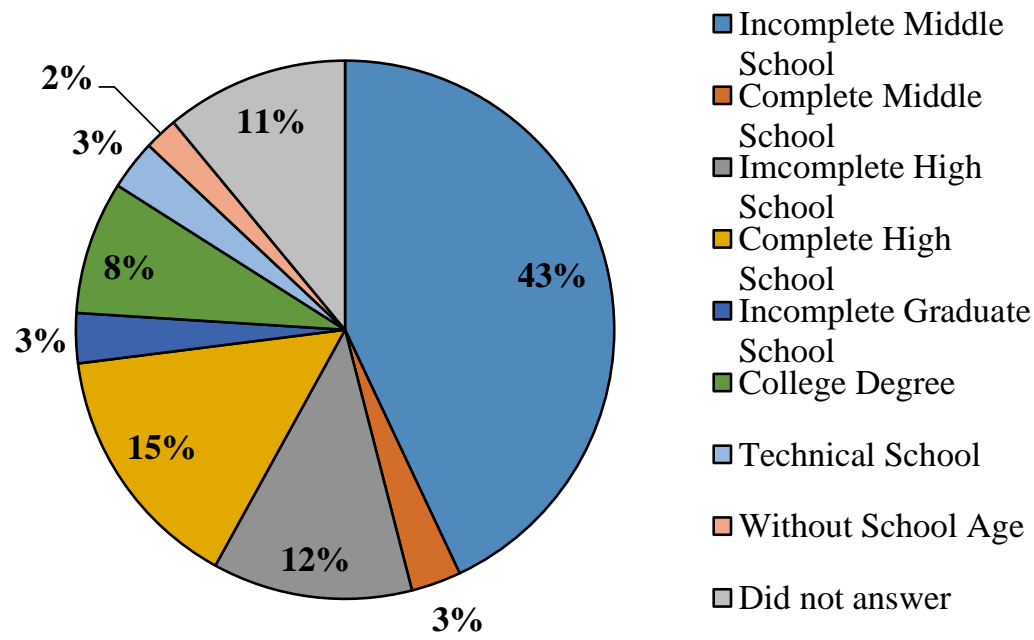

Figure 1. Level of schooling of the members of the families of the rural properties in Senhora de Oliveira, Minas Gerais.

Figura 1. Nível de escolaridade dos membros das famílias das propriedades rurais em Senhora de Oliveira, Minas Gerais.

Regarding heads of households, $85 \%$ are over 40 years old. Among the 20 properties, $70 \%$ have family labor, and $25 \%$ have help from others, a relationship characterized by the exchange of services between producers.

The rural properties evaluated have an area of less than 150 ha, with $90 \%$ of them not exceeding 40 ha (Figure 2). The source of income for $45 \%$ of respondents comes from rural activity; $40 \%$ count on retirement for sustenance, and the rest have other sources of income, which is consistent with the age group of the rural producers interviewed.

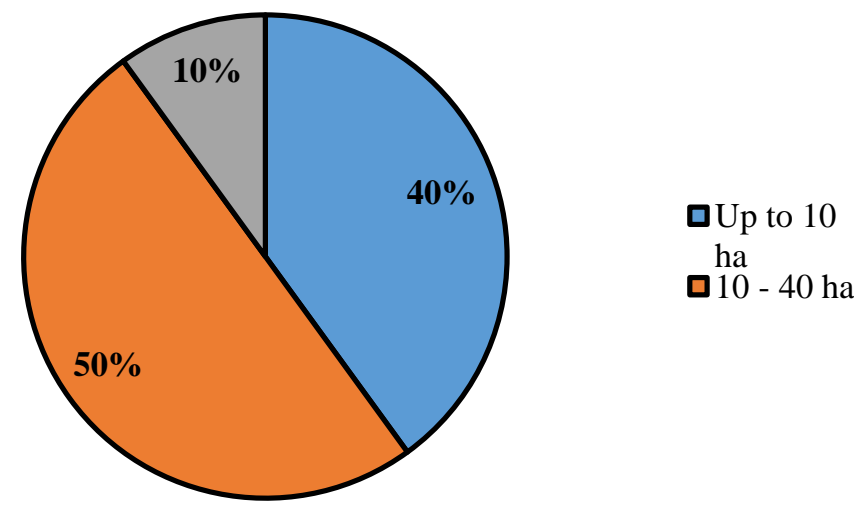

Figure 2. Area of rural properties in Senhora de Oliveira, Minas Gerais.

Figura 2. Área das propriedades rurais em Senhora de Oliveira, Minas Gerais.

FLORESTA, Curitiba, PR, v. 51, n. 1, p. 090-098, jan/mar 2021. 
Rural activities carried out on rural properties are intended for production for sale and subsistence. The main income-generating activity for families is dairy farming, handicrafts, and eucalyptus culture. The latter was identified in $25 \%$ of the rural properties visited. The most relevant subsistence activities observed were fruit cultivation, corn, and bean cultivation.

\section{Environmental profile}

\section{Legal Reserve Areas (LR)}

Among the 20 rural properties that participated in the rural diagnosis, 35\% have delimited LR areas, and none of them have a management plan. LR exploration takes place in $15 \%$ of the properties evaluated, with the production of firewood and cuttings being the predominant activity. Regarding the state of conservation of the LR, $43 \%$ were considered conserved, $43 \%$ disturbed, and 14\% degraded. Almost all LR areas' occupation occurred with native forests, with $50 \%$ in the initial stage and $50 \%$ in the advanced stage.

\section{Permanent Preservation Areas (PPA)}

All properties have some variety of PPA, but none of them showed $100 \%$ compliance with the current forest legislation for PPAs and LR in rural properties. The successional stages found in PPAs occupied with native forests were the initial and the medium. The initial succession stage was identified in 69\% of the PPAs, $17 \%$ in the medium stage, and $14 \%$ in the advanced stage. The "disturbed" conservation status accounted for $66 \%$ of the PPA areas. In $25 \%$ of them, there is a native forest. Pastures, degraded or not, are present in rural properties and $53 \%$ of PPAs. The areas around the springs are found in $80 \%$ of rural properties in a "disturbed" state of conservation and do not occupy a radius of 50 meters (Figure 3).

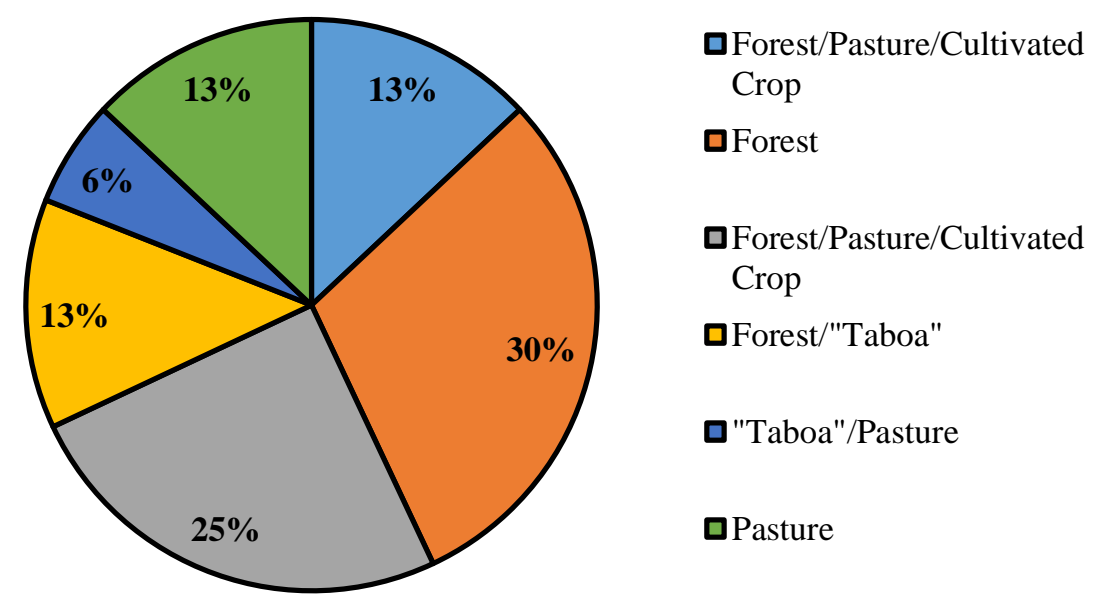

Figure 3. Soil occupation in the surroundings of the spring areas in the rural properties in Senhora de Oliveira, Minas Gerais.

Figura 3. Ocupação do solo no entorno das áreas de nascente nas propriedades rurais em Senhora de Oliveira, Minas Gerais.

\section{Water resources}

Among the 20 rural properties, $65 \%$ have streams, $80 \%$ have springs, $35 \%$ have dams, streams, and/or brooks, and $15 \%$ have rivers that flow within the property boundaries. The general state of conservation of water resources in rural properties is characterized as "disturbed" (Figure 4). 


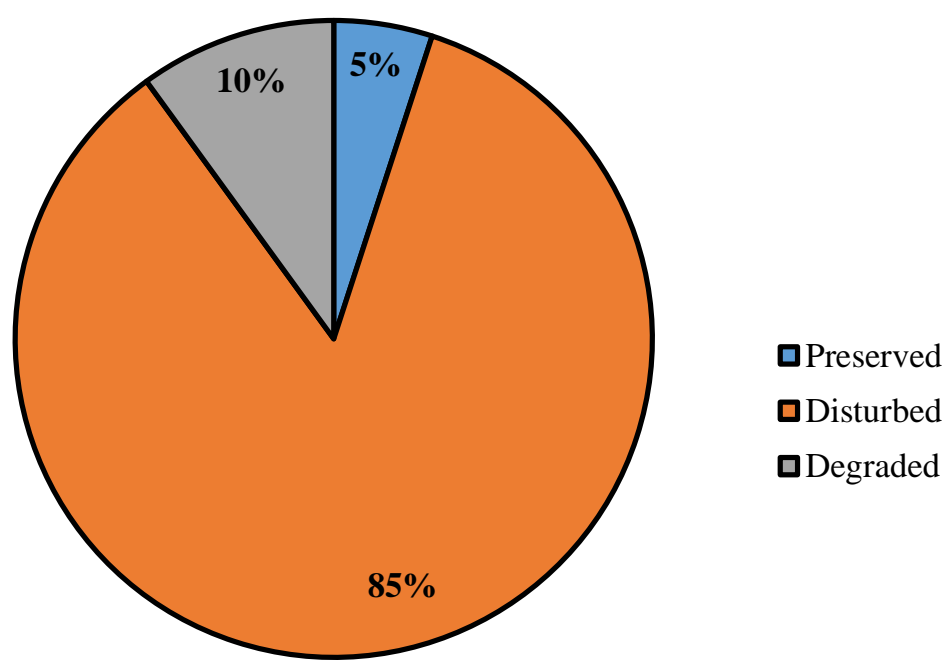

Figure 4. Conservation status of water resources in rural properties in Senhora de Oliveira, Minas Gerais.

Figura 4. Estado de conservação dos recursos hídricos nas propriedades rurais em Senhora de Oliveira, Minas Gerais. in $72 \%$.

The springs observed in the properties were conserved in $18 \%$ of the total, degraded in $10 \%$, and disturbed

\section{Willingness to receive}

The average amount of disposition to be received by rural producers was $\mathrm{R} \$ 220.00 \mathrm{ha}^{-1}$ year ${ }^{-1}$, in which those producers who did not answer this question were not considered. Most of the evaluated rural owners (35\%) did not know how to answer a value of willingness to receive for the environmental conservation of their PPAs.

\section{DISCUSSIONS}

The region of the forest zone in Minas Gerais is one of the poorest in the state, with the highest concentration of income located in the micro-regions of Juiz de Fora, Cataguases, and Uba due to the higher concentration of income resulting from industrial activities (FARIA et al., 2018). The other regions' characteristics are lower Gross Domestic Product (GDP) per capita (NASCIMENTO et al., 2015), low Human Development Index (HDI), and low level of education of rural producers. In Senhora de Oliveira, among rural producers, elementary and incomplete high school are the predominant level of education.

The tax module in Senhora de Oliveira is 22 ha. That is, the farmer with a property of less than 88 ha is considered a small rural producer. In rural properties with these characteristics, if the rural producer complies with all the current environmental legislation, achieving economic success becomes a challenge, with subsistence agriculture predominating. Among the rural producers in the municipality, in the 20 properties, more than $50 \%$ of them have less than four fiscal modules. PES is an essential alternative to preserve the environment and its ecosystem services generated and create an alternative income for rural producers in this situation (EZZINE DE BLASS et al., 2019).

Most of the rural producers did not know how to inform the value of willingness to receive for the environmental conservation of their PPAs. It shows the lack of a market for environmental goods and services to guide the economic valuation of the environment and the implementation of the PES. Thus, its implementation can be an opportunity for the municipality's rural producer, for environmental preservation, and, mainly, a source of extra income that (until then) was not recognized by the market.

PES programs in Brazil, in some cases, are used as an essential tool in forest restoration and subsequent protection of the LR and PPA areas (RICHARDS et al., 2015). LR areas in Brazil represent 13\% of the country's entire territorial extension (OAKLEAF et al., 2017), and their protection does not always occur. In the municipality of Senhora de Oliveira, the LR areas were considered disturbed or degraded in more than $50 \%$ of the evaluated rural properties, which shows the difficulty in conserving these areas. PPA areas are also in critical condition,

FLORESTA, Curitiba, PR, v. 51, n. 1, p. 090-098, jan/mar 2021. 
considered disturbed in $66 \%$ of cases, which is a typical reality of degradation of PPA areas in springs in the country (SANTOS et al., 2016).

The water resources conservation in the municipality of Senhora de Oliveira is critical, with only $5 \%$ of them in a conserved state. PES programs for water conservation can be developed to solve this - such as the Oasis project in Apucarana, Parana, and the Conservador de Águas (Water Conservator) in Extrema, Minas Gerais. The users' participation in a given hydrographic basin is necessary for the implementation of these programs and for them to know the potential effects of water management (ZANELLA et al., 2014).

Rural producers in Senhora de Oliveira were optimistic about the implementation of a PES program in the region, with an average amount of willingness to receive $\mathrm{R} \$ 220,00 \mathrm{ha}^{-1}$ year $^{-1}$. The amount sought by rural producers in the municipality is similar to the values already earned in Extrema ( $\mathrm{R} \$ 262,00 \mathrm{ha}^{-1}$ year $\left.^{-1}\right)$ and Apucarana ( $\mathrm{R} \$ 196,00 \mathrm{ha}^{-1}$ year $\left.^{-1}\right)$, which comprise 210 and 133 registrations of rural producers in the programs, respectively (TAFFARELLO et al., 2017). A socioeconomic and environmental diagnosis occurred in four municipalities in the forest area of Minas Gerais (Alto do Rio Doce, Bras Pires, Cipotanea, and Desterro do Melo). It found a value of willingness to receive by rural producers of $\mathrm{R} \$ 160,00 \mathrm{ha}^{-1}$ year ${ }^{-1}$, which shows their interest in implementing a PES program in the region and that the rate varies according to the agricultural activities carried out in these municipalities (VILAR et al., 2010).

PES initiatives have great potential as a strategic alternative for environmental conservation in Brazil. However, the challenge is the definition of concrete methodologies to define how much the rural landowners should receive as compensation, linking the opportunity cost of the land, indexes for quality, and total conserved area. The involvement of local authorities and public managers is considered a crucial step to assist in obtaining funding sources for PES programs (YOUNG; BAKKER, 2014). Some countries already have efficient examples of PES. Besides, the Brazilian Forestry Code allows its use, even if it does not specify how it will be operationalized.

\section{CONCLUSIONS}

- The 20 rural properties evaluated have majorly disturbed and degraded legal reserve, the permanent preservation areas have a disturbed state of conservation and degraded water resources, which indicates that conservation actions must be implemented in the municipality to ensure maintenance provision of environmental services.

- Rural producers are interested in participating in the PES, and their willingness to receive is, on average, similar to that practiced in some Payments for Environmental Services initiatives in Brazil (R \$220.00 $\mathrm{ha}^{-}$ ${ }^{1}$ year $\left.^{-1}\right)$.

- The municipality of Senhora de Oliveira has the necessary conditions to implement the PES. However, producers still do not receive any incentive to provide environmental services. If the implementation of this Payments for Environmental Services process occurs, there will surely be advances in environmental conservation and will bring social benefits throughout the region.

- The difficulty in determining the willingness to receive for environmental preservation is a challenge for the implementation of PES in the municipality and an opportunity, as it is an alternative for environmental preservation and a source of extra income for the producer.

\section{REFERENCES}

BRASIL. Lei Federal n 4.771, de 15 de setembro de 1965. Institui o novo Código Florestal. Diário Oficial da União, Brasília, DF, quinze de setembro de $1965 . \quad$ Disponível em: <http://www.planalto.gov.br/ccivil_03/leis/14771.htm> Acesso em: 20/05/2019.

BRASIL. Lei $n^{\circ}$ 12.651, de 25 de maio de 2012. Dispõe sobre a proteção da vegetação nativa; altera as Leis nos 6.938, de 31 de agosto de 1981, 9.393, de 19 de dezembro de 1996, e 11.428, de 22 de dezembro de 2006; revoga as Leis $\mathrm{n}^{\circ} \mathrm{s}$ 4.771, de 15 de setembro de 1965, e 7.754, de 14 de abril de 1989, e a Medida Provisória no 2.166-67, de 24 de agosto de 2001; e dá outras providências. Diário Oficial da União, Brasília, DF, vinte cinco de maio de 2012. Disponível em: <http://www.planalto.gov.br/ccivil_03/_ato2011-2014/2012/lei/112651.htm> Acesso em: 20/05/2019.

COELHO, F. M. G. A arte das orientações técnicas no campo: concepções e métodos. Viçosa, MG: UFV, 2014. $188 \mathrm{p}$. 
CONAMA. Resolução CONAMA n 303, de 20 de março de 2002. Dispõe sobre parâmetros, definições e limites de Áreas de Preservação $\quad$ Permanente. Disponível em:<http://www2.mma.gov.br/port/conama/legiabre.cfm?codlegi=299> Acesso em: 20/05/2019.

CONAMA. Resolução CONAMA no 392, de 25 de junho de 2007. Definição de vegetação primária e secundária de regeneração de Mata Atlântica no estado de Minas Gerais. Disponível em: <http://www2.mma.gov.br/port/conama/legiabre.cfm?codlegi=537> Acesso em: 20/05/2019.

COSTANZA, R.; GROOT, R.; SUTTON, P.; PLOEG, S.; ANDERSON, S. J.; KUBISZEWSKI, I.; FARBER, S.; TURNER, R. K. Changes in the global value of ecosystem services. Global Environmental Change, v. 26, n. 1, p. 152 - 158, 2014. Doi: https://doi.org/10.1016/j.gloenvcha.2014.04.002.

EZZINE-DE-BLAS, D.; CORBERA, E.; LAPEYRE, R. Payments for Environmental Services and Motivation Crowding: Towards a Conceptual Framework. Ecological Economics, v. 156, n. 1, p. 434 - 443, 2019. Doi: https://doi.org/10.1016/j.ecolecon.2018.07.026.

FARIA, W. R.; JÚNIOR, A. A. B.; SANTIAGO, F. S.; REIS, F. S.; MONTENEGRO, R. L. G. Estrutura socioeconômica, vantagens competitivas e padrão regional: avaliando as disparidades da zona da mata de Minas Gerais em 2010. Revista Brasileira de Estudos Regionais e Urbanos, v. 12, n. 1, p. 51 - 72, 2018.

GARRETT, R. D.; LEVY, S.; CARLSON, K. M.; GARDNER, T. A.; GODAR, J.; CLAPP, J.; DAUVERGNE, P.; HEILMAYR, R.; WAROUX, Y. P.; AYRE, B.; BARR, R.; DØVRE, B.; GIBBS, H. K.; HALL, S.; LAKE, S.; MILDER, J. C.; RAUSCH, L. L. RIVERO, R.; RUEDA, X.; SARSFIELD, R.; SOARES-FILHO, B.; VILLORIA, N. Criteria for effective zero-deforestation commitments. Global Environmental Change, v. 54, n. 1, p. 135 147, 2019. Doi: https://doi.org/10.1016/j.gloenvcha.2018.11.003.

MURADIAN, R.; ARSEL, M.; PELLEGRINI, L.; ADAMAN, F.; AGUILAR, B.; AGARWAL, B.; CORBERA, E.; EZZINE-DE-BLAS, D.; FARLEY, F.; FROGER, G.; GARCIA-FRAPOLLI, E.; GÓMEZ-BAGGETHUN, E.; GOWDY, J.; KOSOY, N.; LE COQ, J. F.; LEROY, P.; MAY, P.; MÉRAL, P.; MIBIELLI, P.; NORGAARD, R.; OZKAYNAK, B.; PASCUAL, U.; PENGUE, W.; PEREZ,. M.; PESCHE, D.; PIRARD, R.; RAMOS-MARTIN, J.; RIVAL, L.; SAENZ, F.; VAN HECKEN, G.; VATN, A.; VIRA, B.; URAMA, K.Payments for ecosystem services and the fatal attractionof win-win solutions. Policy Perspective, v. 6, n. 4, p. 274 - 279, 2013. Doi: https://doi.org/10.1111/j.1755-263X.2012.00309.x.

NASCIMENTO, L. M.; COSTA, I. S.; OLHER, B. S. Gastos públicos com educação: a análise da eficiência dos municípios da zona da mata mineira. Revista de Ciências da Educação, v. 32, n. 1, p. 119 - 143, 2015.

OAKLEAF, J. R.; MATSUMOTO, M.; KENNEDY, C. M.; BAUMGARTEN, L.; MITEVA, D.; SOCHI, K.; KIESECKER, J. LegalGEO: Conservation tool to guide the siting of legal reserves under the Brazilian Forest Code. Applied Geography, v. 86, n. 1, p. 53 - 65, 2017. Doi: https://doi.org/10.1016/j.apgeog.2017.06.025.

PINTO, L. V. A.; BOTELHO, S. A.; DAVIDE, A. C.; FERREIRA, E. Estudo das nascentes da bacia hidrográfica do Ribeirão Santa Cruz, Lavras, MG. Scientia Forestalis, n. 65, p. 197 - 206, 2004.

RICHARDS, R. C.; REROLlE, J.; ARONSON, J.; PEREIRA, P. H.; GONÇALVES, H.; BRACALION, P. H. S. Governing a pioneer program on payment for watershed services: Stakeholder involvement, legal frameworks and early lessons from the Atlantic forest of Brazil. Ecosystem Services, v. 16, n. 1, p. 23 - 32, 2015. Doi: https://doi.org/10.1016/j.ecoser.2015.09.002.

RUGGiERO, P. G. C.; METZGER, J. P.; TAMBOSI, L. R.; NICHOLS, E. Payment for ecosystem services programs in the Brazilian Atlantic Forest: Effective but not enough. Land Use Policy, v. 82, n. 1, p. 283 - 291 , 2019. Doi: https://doi.org/10.1016/j.landusepol.2018.11.054.

SANTOS, A. R.; CHIMALli, T.; PELUZIO, J. B. E.; SIlVA, A. G.; SANTOS, G. M. A. D. A.; LORENZON, A. S.; TEIXEIRA, T. R.; CASTRO, N. L. M.; RIBEIRO, C. A. A. S. Influence of relief on permanent preservation áreas. Science of The Total Environment, v. 541, n. 1, p. 1296 - 1302, $2016 . \quad$ Doi: https://doi.org/10.1016/j.scitotenv.2015.10.026.

SONE, J. S.; GESUALDO, G. C.; ZAMBONI, P. A. P.; VIEIRA, N. O. M.; MATTOS, T. S.; CARVALHO, G. A.; RODRIGUES, D. B. B.; SOBRINHO, T. A.; OLIVEIRA, P. T. S. Water provisioning improvement through payment for ecosystem services. Science of The Total Environment, v. 655, n. 1, p. 1197 - 1206, 2019. Doi: https://doi.org/10.1016/j.scitotenv.2018.11.319.

FLORESTA, Curitiba, PR, v. 51, n. 1, p. 090-098, jan/mar 2021.

Schettini, B. L.S. et.al.

ISSN eletrônico 1982-4688 
SOUZA, M. M. O. A utilização de metodologias de diagnóstico e planejamento participativo em assentamentos rurais: o diagnóstico rural/rápido participativo (DRP). Em Extensão, v. 8, n. 1, p. 34 - 47, 2009.

TAFFARELlO, D.; CALIJURI, M. C.; VIANI, R. A. G.; MARENGO, J. A.; MENDIONDO, E. A. Hydrological services in the Atlantic Forest, Brazil: An ecosystem-based adaptation using ecohydrological monitoring. Climate Services, v. 8, n. 1, p. 1 - 16, 2017. Doi: https://doi.org/10.1016/j.cliser.2017.10.005.

VARELA, C. A.; PISSARRA, T. C. T.; MARTINS FILHO, M. V.; VALlE JUNIOR, R. F.; SANCHES FERNANDES, L. F.; PACHECO, F. A. L. A legal framework with scientific basis for applying the 'polluter pays principle' to soil conservation in rural watersheds in Brazil. Land Use Policy, v. 66, n. 1, p. 61 - 71, 2017. Doi: https://doi.org/10.1016/j.landusepol.2017.04.036.

VILAR, M. B.; OLIVEIRA, A. C. C.; JACOVINE, L. A. G.; FERREIRA, M. G.; SOUZA, A. L. Valoração ambiental de propriedades rurais de municípios da bacia hidrográfica do rio xopotó, MG. Cerne, v. 16, n. 4, p. 539 - 545, 2010. Doi: http://dx.doi.org/10.1590/S0104-77602010000400013.

WANG, P.; WOLF, S. A. A targeted approach to payments for ecosystem services. Global Ecology and Conservation (NO PRELO). Doi: https://doi.org/10.1016/j.gecco.2019.e00577.

WUNDER; S. 2005. Payments for Environmental Services: Some Nuts and Bolts CIFOR Occasional paper (2005). Disponível em: <https://www.cifor.org/publications/pdf_files/OccPapers/OP-42.pdf> Acesso em: 20/05/2019.

YOUNG, C. E. F.; BAKKER, L. B. Payments for ecosystem services from watershed protection: A methodological assessment of the Oasis Project in Brazil. Natureza e Conservação, v. 12, n. 1, p. 71 - $78,2014$. Doi: https://doi.org/10.4322/natcon.2014.013.

ZANELLA, M. A.; SCHLEYER, C.; SPEELMAN, S. Why do farmers join Payments for Ecosystem Services (PES) schemes? An Assessment of PES water scheme participation in Brazil. Ecological Economics, v. 105, n. 1, p. 166 - 176, 2014. Doi: https://doi.org/10.1016/j.ecolecon.2014.06.004. 